\title{
Biochemical and Bacteriological properties of fresh and frozen sold cephalopods in the Egyptian market.
}

\author{
Howaida R. Gabr \\ Department of Marine Science, Faculty of Science, Suez Canal University, Ismailia, \\ Egypt.
}

\begin{abstract}
$\mathrm{V}$ arious cephalopods are available for seafood consumers in the Suez Canal area either caught from the Suez Canal and stored in ice during transporting and marketing or imported and sold frozen in retail market. The lower price of imported cephalopods compared with the fresh ones makes it more demanded by consumers, restaurants and hotels. The objective of this study is to evaluate the quality and safety of fresh/chilled squid (Uroteuthis duvauceli) and cuttlefish (Sepia pharaonis) compared to frozen imported squid in the Egyptian market through chemical, biochemical and bacteriological analyses. The chemical analysis revealed that the mantle tissue $\mathrm{pH}$, volatile base nitrogen (VBN) and trimethylamine (TMA) in frozen squid were significantly higher $(P<0.05)$ than that in fresh/chilled samples. The biochemical analysis showed that the crude protein content $(\%$ dry weight) was significantly lower $(P<0.05)(14.2 \pm 0.73 \%)$ in frozen samples than that in fresh squid and cuttlefish $(17.25 \pm 0.41 \%$ \& $19.95 \pm 0.55 \%$ respectively). The total lipid content was generally low, ranging from $0.39-1.77 \%$ in all samples. Most of saturated fatty acid content of the three samples was presented as C16:0, monounsaturated fatty acid content as C18:1 and polyunsaturated fatty acid (PUFA) content as eicosapentaenoic acid (EPA, C20:5n-3) and docosahexaenoic (DHA, C22:6n-3). EPA and DHA contents were significantly lower $(P<0.05)$ in frozen squid than in fresh samples. The major essential amino acids (EAA) in the three samples were lysine, arginine, and leucine. The major non-essential amino acids (NEAA) were glutamic acid, aspartic acid and glycine. EAA and NEAA values were significantly lower $(P<0.05)$ in frozen squid than in fresh cuttlefish. Bacteriological results suggest that hydrogen sulphide producing bacteria constituted a significant proportion of the total spoilage flora in frozen samples, while Pseudomonas sp. constituted a major part of the spoilage flora of fresh samples. An overall look into the data obtained showed that there might be significant health hazards to humans from consuming imported frozen squid besides its much lower nutritional value than fresh samples.
\end{abstract}

Keywords: frozen squid, fresh/chilled squid, cuttlefish, chemical analysis, biochemical analysis, bacterial count. 


\section{INTRODUCTION}

Cephalopods represent important economic seafood for human consumption as they contribute $14 \%$ of the world fisheries, according to FAO (2004). Of the species explored worldwide, roughly $41 \%$ belong to the genera Loligo, Sepia or Octopus, which are predominantly found on the continental shelf (Guerra, 1996). Cephalopods, like fishes and crustaceans, are rapidly perishable products; their sensory quality decrease quickly after capture. However, the shelf-life of cephalopods is much shorter (approximately between $50 \%$ and $80 \%$ ) than for most fish species stored in similar temperatures and conditions (Kreuzer, 1984). The rejection time for cephalopods products is always around 10 days for cuttlefish and 9 days for squid (Vaz-Pires et al., 2008). This indicates that the spoilage process in cephalopods is different from fish due to many reasons, including their thinner and fragile skin, nutritional composition that is more liable to enzymatic degradation, shorter and less pronounced rigor mortis and initial autolytic degradation for a longer period (Vaz-Pires \& Seixas, 2006).

In Egypt, particularly in Suez Canal area, the squid Uroteuthis duvauceli, and the cuttlefish Sepia pharaonis are the most commonly-consumed cephalopods in the fish market. They are sold as fresh product covered with ice to increase their shelf-life. Recently during the last few years, the consumption of frozen imported seafood including cephalopods mainly the squid has increased in Egypt. The mantle is the only body part that is sold without head, skin and viscera to consumers. Despite frozen and thawed products have a lower quality and poor flavor than fresh ones (Kreuzer, 1984), there is a growing tendency of consumers, restaurants and hotels for their consumption due to their marked lower price.

Meanwhile, the topic of seafood safety and quality assurance is one of the most important and timely issues directly linking the oceans and human health considerations (Tyson et al., 2004). Seafood is generally the main contributor of n-3 PUFA in the human diet. Lipids of marine fish species are generally characterized by high levels of long-chain $n-3$ polyunsaturated fatty acids (Ackman, 1989). Among the polyunsaturated fatty acids, EPA (eicosapentaenoic acid, C20:5 n-3) and DHA (docosahexaenoic acid, C22:6 $n-3)$ are the dominant $n-3$ fatty acids in marine fish (Ackman, 1989). These fatty acids are of great importance to humans for the prevention of coronary heart disease (Mozaffarian et al., 2005). Although cephalopods contain low levels of fat, it is rich in n-3 fatty acids (Zlatanos et al., 2006). While, seafood can be a highly nutritious component of human diet, the contaminated, imported or domestic seafood can cause foodborne illnesses, with problems ranging from mild gastrointestinal discomfort to neurological damage (GAO, 2001). The storage method seems to influence the quality characteristics of seafood especially cephalopods (GAO, 2001). Although frozen storage can inhibit microbial spoilage, tissue proteins undergo a number of changes, which modify 
their structural and functional properties (Mackie, 1982). These changes include protein insolubility, formation of aggregates, mechanical damage and enzymes and other components are released (Nilsson \& Ekstrand, 1993).

To our knowledge, no studies on commercial cephalopods quality and safety are so far reported in Egypt. However, in general few studies on cephalopods quality were directed mostly to the squid (Ruíz-Capillas et al., 2002a\&b; Albaneses et al., 2005) and Octopus (Lougovois et al., 2007; Atrea et al., 2009). Therefore, from the nutritional point of view, the objectives of this research are: 1- Comparison of the chemical $(\mathrm{pH}$, trimethylamine and volatile base nitrogen) and biochemical composition of the most commonly consumed fresh chilled cephalopods in the Suez Canal area with the imported frozen squid in the market. 2- Check the microbiological status to detect pathogenic bacteria which are possible indications of contamination or poor processing practices.

\section{MATERIALS AND METHODS}

\section{Samples}

Fresh chilled squid and cuttlefish were purchased from local fish market. They were caught along the coast of Suez Canal. Frozen imported squids were bought from a supermarket. A total of 8 individuals from each sort were used for all analyses. Mean values of mantle length and body weight of all the samples were $23.7 \pm 2.71 \mathrm{~cm}$ and $144 \pm 10.2 \mathrm{~g}$ for Uroteuthis duvauceli, $15.3 \pm$ $4.38 \mathrm{~cm}$ and $220 \pm 14.62 \mathrm{~g}$ for Sepia pharaonis, and $30 \pm 1.11 \mathrm{~cm}$ and $220 \pm$ $4.11 \mathrm{~g}$ for frozen squids. All the samples were stored in the Lab under the same conditions of market storage. The fresh samples were kept among ice cubes in a box with perforated bottom and new ice was added as needed, while the frozen squid were stored at $-20{ }^{\circ} \mathrm{C}$ until analysis. All the sample analyses were done within two days of arrival to the Lab on only the mantle part, which is the main edible portion of cephalopods. The analyses were performed on two replicates.

\section{Chemical Analysis pH measurement}

Ten gram of each sample were blended with $20 \mathrm{ml}$ distilled water in a blender for $30 \mathrm{~s}$ and $\mathrm{pH}$ value of each sample homogenate was measured by a digital $\mathrm{pH}$-meter standardized at $\mathrm{pH} 4$ and 7.

\section{Trimethylamine (TMA) and volatile base nitrogen (VBN)}

Mantle extracts for determination of trimethylamine (TMA) and volatile basic nitrogen (VBN) that includes TMA, other volatile amines and ammonia were prepared by homogenizing $10 \mathrm{~g}$ of minced mantle with $20 \mathrm{ml} 5 \%$ trichloroacetic acid (TCA) for 1 min using an Ultra-Turrax homogenizer. The homogenate was centrifuged $\left(1200 \mathrm{x} \mathrm{g}, 4 \mathrm{~min}, 18^{\circ} \mathrm{C}\right)$ and the extract filtered in filter paper. The precipitate was washed twice with $10 \mathrm{ml} \mathrm{5 \%} \mathrm{TCA,} \mathrm{centrifuged}$ and filtered. The extracts were $10 \mathrm{ml} 5 \%$ TCA, centrifuged and filtered. The extracts were collected and diluted to $50 \mathrm{ml}$ with 5\% TCA in a volumetric flask and kept refrigerated at $4{ }^{\circ} \mathrm{C}$ until required. Contents of trimethylamine and 
volatile base nitrogen were determined in these muscle extracts according to the procedure of Howgate (1976).

\section{Biochemical analysis \\ Proximate composition}

Moisture, total protein, total lipid, total carbohydrates and ash were determined as percentage: (wet weight of biochemical content (g) per $\mathrm{g}$ of mantle tissue) x 100 according to the procedure of AOAC (1998).

\section{Fatty acids analysis}

Fatty acids in the mantle samples were determined using the procedure of Cohen et al. (1988). Fatty acid methyl esters were analyzed using a gas liquid chromatography on a Hewlett Pachard 6890 series fitted with a flame ionization detector and a split-splitless injector. The separation was carried out with helium as the carrier gas in an INNO wax capillary column, programmed from $150^{\circ} \mathrm{C}$ to $200^{\circ} \mathrm{C}$ at $4^{\circ} \mathrm{C} \mathrm{min}^{-1}$, held for $10 \mathrm{~min}$ and heated to $210{ }^{\circ} \mathrm{C}$, for $15 \mathrm{~min}$, then increased by $1{ }^{\circ} \mathrm{C} \mathrm{min}{ }^{-1}$ up to $220^{\circ} \mathrm{C}$ and finally increased by $10^{\circ} \mathrm{C} \mathrm{min}$ mp $^{-1}$ up $240^{\circ} \mathrm{C}$. Fatty acid methyl esters were identified by comparison of their retention time with those of chromatographic Sigma standards. Peak areas were determined using the Varian software.

\section{Amino acids analysis}

Amino acids in the mantle samples were determined according to the method described by Blackburn (1986). Proteins were hydrolyzed with $6 \mathrm{~N}$ hydrochloric acid (containing $0.1 \%$ phenol) in a MLS-1200 Mega Microwave System (Milestone), at $800 \mathrm{~W}, 160{ }^{\circ} \mathrm{C}$ for $10 \mathrm{~min}$. The hydrolysis was performed under inert and anaerobic conditions to prevent oxidative degradation of amino acids. The hydrolysates were filtered and dissolved in sodium citrate buffer ( $\mathrm{pH}$ 2.2). Amino acids were separated by ion exchange liquid chromatography in an automatic analyzer Biochrom 20 (Amersham Biosciences), equipped with a column filled with a polysulfonated resin $(250 \times 4.6 \mathrm{~mm})$, using three sodium citrate buffers $(\mathrm{pH} \mathrm{3.20,4.25}$, and 6.45; Amersham Biosciences) and three temperatures $\left(50{ }^{\circ} \mathrm{C}, 58{ }^{\circ} \mathrm{C}\right.$, and $\left.95^{\circ} \mathrm{C}\right)$. The detection of amino acids was done at $440 \mathrm{~nm}$ and $570 \mathrm{~nm}$ after reaction with ninhydrin (Amersham Biosciences). Amino acids were identified by comparison of their retention time with those of specific standards (Sigma) and were quantified with the software EZChrom Chromatography Data System, version 6.7 (Scientific Software) using norleucine (Sigma) as internal standard.

\section{Bacteriological Analysis}

Two replicates from each sample were used exclusively for the microbiological examination. Samples were analyzed as recorded in Standard Methods for Examination of Water and Wastewater (APHA, 1992). Individual areas of around $10 \mathrm{~cm}^{2}$ of each mantle were cut and homogenized by a blinder in sterile peptone water $(0.1 \%)$ and from which surface inoculations were made using the $20 \mu \mathrm{l}$ drop method in five solid medium: Plate count agar for total viable bacteria (TVB), Pseudomonas selective agar media for isolation of 
Pseudomonas species (Ps.), T.C.B.S agar medium (Scharlau) for vibrio sp., Triple sugar iron agar for $\mathrm{H}_{2} \mathrm{~S}$-producing bacteria and Endo Agar Base for E.coli, culture media were adopted from the Oxoid Manual (1985), Identification of well-isolated pure colonies proceeded to the generic level based on biochemical tests according to Bergey's Manual (1994). Plates were incubated at $25^{\circ} \mathrm{C}$ for 3 days and black colonies $\left(\mathrm{H}_{2} \mathrm{~S}\right.$-producing bacteria) formed were counted.

\section{Statistical Analysis}

Data were analyzed using an ANOVA to investigate the presence of significant differences in parameters between the fresh/chilled samples and the frozen samples. Significance of differences was defined as $P<0.05$. Statistics were performed using the commercially available software programs "Statistica" and "MS Excel".

\section{Chemical quality}

\section{RESULTS}

Mantle tissue $\mathrm{pH}$ was significantly higher $(P<0.05)$ in frozen squid $(8.0 \pm 0.01)$ than that in fresh/chilled squid $(6.85 \pm 0.01)$ and cuttlefish $(6.51 \pm 0.01)$. There is also significant increase $(P<0.05)$ in volatile base nitrogen $(\mathrm{VBN})$ and trimethylamine (TMA) in frozen squid $(15.93 \pm 0.01 \& 3.2 \pm 0.01$ $\mathrm{mg} / 100 \mathrm{~g}$ respectively) than that in fresh/chilled squid $(13.78 \pm 0.10 \& 2.0 \pm 0.02$ $\mathrm{mg} / 100 \mathrm{~g}$ respectively) and in fresh/chilled cuttlefish $(10.52 \pm 0.20 \& 1.7 \pm 0.02$ $\mathrm{mg} / 100 \mathrm{~g}$ respectively) (Table 1$)$.

Table 1: Means \pm S.D of $\mathrm{pH}$, volatile base nitrogen (VBN) and trimethylamine (TMA) in the mantle tissue of frozen and fresh/chilled cephalopods collected from the Egyptian market.

\begin{tabular}{cccc}
\hline Name & pH & VBN (mg/100g) & TMA (mg/100g) \\
\hline frozen squid & $8.00 \pm 0.01$ & $15.93 \pm 0.01$ & $3.2 \pm 0.01$ \\
fresh/chilled squid & $6.85 \pm 0.01$ & $13.78 \pm 0.10$ & $2.0 \pm 0.02$ \\
fresh/chilled cuttlefish & $6.51 \pm 0.01$ & $10.52 \pm 0.20$ & $1.7 \pm 0.02$ \\
\hline
\end{tabular}

\section{Proximate composition}

Mantle proximate compositions of frozen and fresh/chilled samples are presented in Table 2. All the proximate composition values of the three samples were found to be significantly different $(p<0.05)$. Frozen squids were found to have higher water content $(82.1 \pm 0.20 \%)$ than in fresh squids $(78.65 \pm 0.04 \%)$ and fresh cuttlefish $(75.74 \pm 0.18 \%)$. In contrast, the protein content was lower in frozen squids $(14.20 \pm 0.73 \%)$ than in fresh squids $(17.25 \pm 0.41 \%)$ and fresh cuttlefish $(19.95 \pm 0.55 \%)$. The lipid contents of the three samples were found to be very low.

The highest lipid content was recorded in fresh squids $(1.77 \pm 0.13 \%)$ followed by frozen squid $(1.41 \pm 0.15 \%)$ and fresh cuttlefish $(0.39 \pm 0.02 \%)$.

Table 2: Means \pm S.D of proximate composition (wet weight $\%$ ) in the mantle tissue of frozen and 
fresh/chilled cephalopods collected from the Egyptian market.

\begin{tabular}{lccccc}
\hline \multicolumn{5}{c}{ Composite } & \\
\hline Name & Moisture & Protein & Lipid & Carbohydrate & Ash \\
\hline Frozen squid & $82.10 \pm 0.20$ & $14.20 \pm 0.73$ & $1.41 \pm 0.15$ & $1.09 \pm 0.55$ & $1.20 \pm 0.04$ \\
Fresh/chilled squid & $78.65 \pm 0.04$ & $17.25 \pm 0.41$ & $1.77 \pm 0.13$ & $1.78 \pm 0.51$ & $0.55 \pm 0.01$ \\
Fresh/chilled cuttlefish & $75.74 \pm 0.18$ & $19.95 \pm 0.55$ & $0.39 \pm 0.02$ & $2.46 \pm 0.60$ & $1.46 \pm 0.1$ \\
\hline
\end{tabular}

Meanwhile, the highest carbohydrate content was recorded in fresh cuttlefish $(2.46 \pm 0.60 \%)$ followed by fresh squids $(1.78 \pm 0.51 \%)$ and frozen squids $(1.09 \pm 0.55 \%)$. Ash formed the highest value in fresh cuttlefish $(1.46 \pm 0.1 \%)$ followed by frozen squids $(1.20 \pm 0.04 \%)$ and fresh squids $(0.55 \pm 0.01 \%)$.

\section{Fatty acid profiles}

A wide variety of fatty acids were detected among the lipids in the mantle of the three samples (Table 3). Most of the saturated fatty acid content was represented by palmitic acid (C16:0), monounsaturated fatty acid content by oleic (C18:1) and polyunsaturated fatty acid (PUFA) content as eicosapentaenoic acid (EPA, C20:5n-3) and docosahexaenoic (DHA, C22:6n-3).

Table 3: Saturated and unsaturated lipids \{percentage $=[$ weight $(\mathrm{g})$ of fatty acid per one gram of mantle wet weight] $x 100\}$ in the mantle tissue of frozen and fresh/chilled cephalopods collected from the Egyptian market.

The values are expressed as means \pm standard deviation, $\mathrm{n}=2$. nd: not detected

\begin{tabular}{|c|c|c|c|c|c|}
\hline & & & Frozen squid & Fresh/chilled squid & Fresh/chilled cuttlefish \\
\hline Degree of Saturation & Acid & Symbol & Mean \pm SD & Mean \pm SD & Mean \pm SD \\
\hline \multirow[t]{6}{*}{ Saturated Fatty Acids } & Lauric & C12:O & $2.83 \pm 0.21$ & $1.14 \pm 0.32$ & $0.15 \pm 0.18$ \\
\hline & Myristic & C14:O & $6.57 \pm 0.12$ & $6.21 \pm 1.20$ & $01.80 \pm 0.20$ \\
\hline & Palmitic & C16:O & $33.70 \pm 2.10$ & $32.61 \pm 1.30$ & $24.56 \pm 1.10$ \\
\hline & Stearic & C18:O & $6.57 \pm 0.59$ & $4.20 \pm 0.08$ & $05.10 \pm 0.72$ \\
\hline & Arachidic & C20:O & nd & $0.31 \pm 0.01$ & $01.45 \pm 0.03$ \\
\hline & Behenic & C22:O & nd & $0.15 \pm 0.00$ & $0.27 \pm 0.01$ \\
\hline Total Saturated Acids & & & 49.68 & 44.63 & 33.34 \\
\hline \multirow[t]{3}{*}{ Mono-Unsaturated Fatty Acids } & Palmiboleic & C16:1 & nd & $0.40 \pm 0.01$ & $5.1 \pm 0.19$ \\
\hline & Oleic & C18:1 & $19.27 \pm 0.13$ & $5.30 \pm 0.21$ & $9.00 \pm 0.14$ \\
\hline & Cis-Eicosenic & C20:1 & $5.75 \pm 0.22$ & $1.00 \pm 0.01$ & $3.51 \pm 0.18$ \\
\hline Total Monounsaturated Acids & & & 25.03 & 6.70 & 17.61 \\
\hline \multirow[t]{4}{*}{ Poly-Unsaturated Fatty Acids } & Omega 6 Linoleic & C18:2 w 6 & $4.08 \pm 0.01$ & $1.21 \pm 0.04$ & $1.75 \pm 0.95$ \\
\hline & Omega 3 Linolenic & C18:3 w 3 & $5.41 \pm 0.30$ & $0.06 \pm 0.01$ & $0.11 \pm 0.02$ \\
\hline & $\begin{array}{l}\text { (EPA) Omega } 3 \\
\text { Eicosapentaenoic }\end{array}$ & C20:5 w 3 & $5.61 \pm 0.11$ & $12.20 \pm 0.11$ & $16.3 \pm 0.04$ \\
\hline & $\begin{array}{l}\text { (DHA) Omega } 3 \\
\text { Docosahexaenoic }\end{array}$ & C22:6 w 3 & $10.20 \pm 0.24$ & $35.20 \pm 0.12$ & $30.89 \pm 0.10$ \\
\hline Total Poly-Unsaturated Acids & & & 25.29 & 48.67 & 49.05 \\
\hline Total Unsaturated Fatty Acids & & & 50.32 & 55.37 & 66.66 \\
\hline
\end{tabular}

The levels of saturated and unsaturated fatty acids of the three samples differ significantly $(P<0.05)$. The lowest mean value of saturated fatty acid fraction was in the fresh cuttlefish $(33.34 \%)$, whereas the highest mean value $(49.68 \%)$ was reported in the frozen squids. In contrast, the lowest mean level of unsaturated fatty acids was found in the frozen squids $(50.32 \%)$ and the highest 
value $(66.66 \%)$ was in the fresh cuttlefish. EPA content was higher in the fresh squids and fresh cuttlefish $(12.20 \pm 0.11 \& 16.3 \pm 0.04 \%$ respectively) than that in frozen squids $(5.61 \pm 0.11 \%)$. DHA comprised the highest percentage levels about $35.20 \pm 0.12 \& 30.89 \pm 0.10 \%$ in fresh squids and fresh cuttlefish respectively compared to $10.20 \pm 0.24$ in frozen squids (Table 3 ).

\section{Amino acid profiles}

The amino acid composition of the three cephalopod samples ( $\%$ of total protein) is shown in Table 4. The major essential amino acids (EAA) were lysine, arginine, and leucine. The major non-essential amino acids (NEAA) were glutamic acid, aspartic acid and glycine. Generally, EAA and NEAA values were significantly higher $(P<0.05)$ in fresh cuttlefish than in fresh and frozen squids. The lowest mean value of EAA $(45.13 \%)$ was in the frozen squids whereas the highest mean value $(58.25 \%)$ was in the fresh cuttlefish followed by fresh squids $(45.86 \%)$. Similarly, the lowest mean value of NEAA was in the frozen squids $(29.51 \%)$, whereas the highest mean value $(39.76 \%)$ was in the fresh cuttlefish followed by fresh squids $(32.41 \%)$.

Table 4: Amino acid composition (\% dry weight) in the mantle tissue of frozen and fresh/chilled cephalopods collected from the Egyptian market.

\begin{tabular}{|c|c|c|c|}
\hline Essential (EAA) & Frozen squid & Fresh/chilled squid & Fresh /chilled cuttlefish \\
\hline Threonine & $2.89 \pm 0.09$ & $2.18 \pm 0.02$ & $2.89 \pm 0.05$ \\
\hline Valine & $3.97 \pm 0.09$ & $3.4 \pm 0.03$ & $3.81 \pm 0.05$ \\
\hline Methionine & $0.43 \pm 0.01$ & nd & $1.00 \pm 0.10$ \\
\hline Isoleucine & $3.67 \pm 0.03$ & $4.9 \pm 0.06$ & $4.95 \pm 0.08$ \\
\hline Leucine & $5.55 \pm 0.02$ & $5.4 \pm 0.07$ & $7.04 \pm 0.11$ \\
\hline Phenylalanin & $4.48 \pm 0.02$ & $4.82 \pm 0.06$ & $5.78 \pm 0.10$ \\
\hline Lysine & $10.16 \pm 0.15$ & $10.87 \pm 0.04$ & $13.54 \pm 0.10$ \\
\hline Histidine & $3.06 \pm 0.10$ & $2.58 \pm 0.09$ & $3.63 \pm 0.09$ \\
\hline Arginine & $5.98 \pm 0.01$ & $6.55 \pm 0.11$ & $8.86 \pm 0.11$ \\
\hline Tyrosine & $4.94 \pm 0.09$ & $5.16 \pm 0.08$ & $6.75 \pm 0.11$ \\
\hline Sum EAA & 45.13 & 45.86 & 58.25 \\
\hline \multicolumn{4}{|l|}{ Non-essential (NEAA) } \\
\hline Glutamic acid Glutamic acid & $643 \pm 0066.43 \pm 0.06$ & $9 \pm 0099 \pm 0.09$ & $11 \pm 01511 \pm 0.15$ \\
\hline Alanine & $6.38 \pm 0.11$ & $4.53 \pm 0.05$ & $6.48 \pm 0.15$ \\
\hline Glycine & $7.26 \pm 0.10$ & $6.55 \pm 0.13$ & $7.83 \pm 0.11$ \\
\hline Serine & $2.22 \pm 0.02$ & $1.67 \pm 0.01$ & $2.22 \pm 0.02$ \\
\hline Asp & $6.29 \pm 0.06$ & $9.65 \pm 0.03$ & $10.27 \pm 0.14$ \\
\hline Prolin & $0.51 \pm 0.07$ & $0.77 \pm 0.01$ & $1.02 \pm 0.03$ \\
\hline Cystine & $0.42 \pm 0.01$ & $0.24 \pm 0.01$ & $0.94 \pm 0.02$ \\
\hline Sum NEAA & 29.51 & 32.41 & 39.76 \\
\hline Sum TAA & 74.64 & 78.27 & 98.01 \\
\hline
\end{tabular}

The values are expressed as means \pm standard deviation,

$\mathrm{n}=2$.nd: not detected

\section{Bacteriological analysis}

Results from bacteriological analysis are presented in Fig.1. TVB and $\mathrm{H}_{2} \mathrm{~S}$ bacteria were massively increased in the frozen squids $\left(14 \times 10^{5} \& 3 \times 10^{5}\right.$ $\mathrm{cfu} / \mathrm{ml}$ respectively). Meanwhile, a relatively low numbers of TVB (1264 x $10^{3}$ $\left.\& 888 \times 10^{3} \mathrm{cfu} / \mathrm{ml}\right)$ and $\mathrm{H}_{2} \mathrm{~S}$ bacteria $\left(1612 \times 10 \& 1 \times 10^{3} \mathrm{cfu} / \mathrm{ml}\right)$ were recorded in fresh squids and fresh cuttlefish respectively. In contrast, Ps and vibrio were detected in low numbers in frozen squids $\left(8 \times 10^{3} \& 872 \times 10 \mathrm{cfu} / \mathrm{ml}\right)$ and a relatively high number in fresh squids $\left(392 \times 10^{2}\right.$ and $\left.2036 \times 10 \mathrm{cfu} / \mathrm{ml}\right)$ and 
fresh cuttlefish $\left(704 \times 10^{2}\right.$ and $\left.1672 \times 10 \mathrm{cfu} / \mathrm{ml}\right)$. E. coli was not detected in all the tested samples.

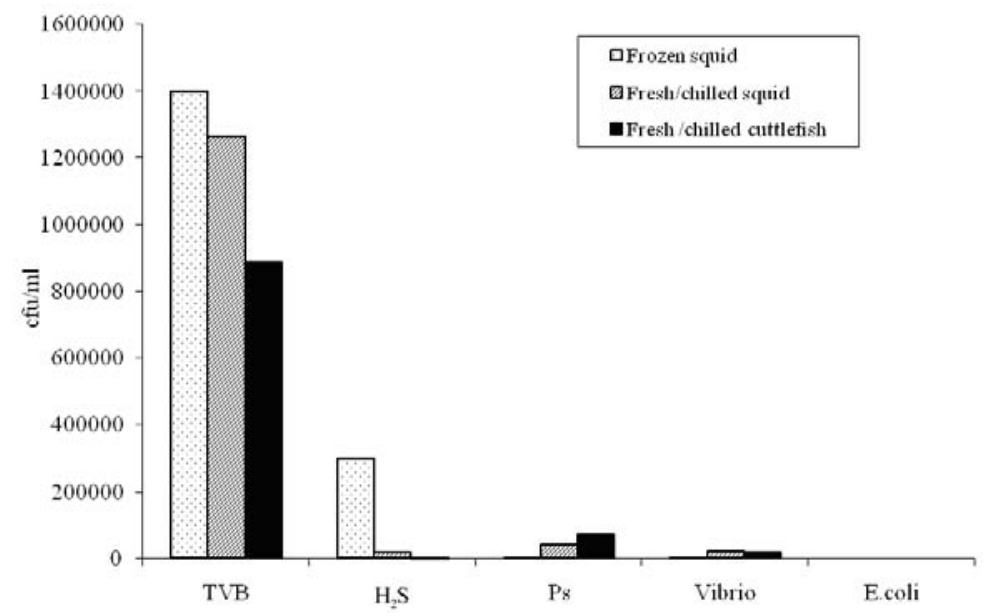

Fig. 1: Microbiological results in the mantle tissue of fresh/chilled and frozen cephalopods collected from the Egyptian market.

Values are means of two replicates measurements.

\section{Chemical quality}

\section{DISCUSSION}

Chemical indices for freshness evaluation of fish, crustaceans and molluscs are mainly based on changes of $\mathrm{pH}$, non-protein nitrogen (NPN) components during the storage, such as trimethylamine (TMA) and volatile basic nitrogen $(\mathrm{VBN})$ that includes the measurement of trimethylamine (produced by spoilage bacteria), dimethylamine (produced by autolytic enzymes during frozen storage), ammonia (produced by the deamination of amino-acids and nucleotide catabolites) and other volatile basic nitrogenous compounds associated with seafood spoilage (Lapa-Guimaraes et al., 2005). In the present study, the fresh chilled squids and cuttlefish $\mathrm{pH}$ was slightly higher $(6.85 \pm 0.01 \& 6.51 \pm 0.01$ respectively) than 5.8, which is a typical value in very fresh products (Sykes et al., 2009). Meanwhile, a significant increase $(P<0.05)$ was recorded in $\mathrm{pH}$ of frozen squids $(8.0 \pm 0.01)$. This value was within the observed range in other studies by Albanese et al. (2005) and Lougovois et al. (2007) who noticed that freezing caused a significant increase of $\mathrm{pH}$ in different cephalopods. They attributed that to the rapid spoilage of the product and the formation of alkaline compounds of autolysis and bacterial metabolites in the muscles.

VBN mean values in fresh chilled squids and cuttlefish $(13.78 \pm 0.1 \&$ $10.52 \pm 0.2 \mathrm{mg} / 100 \mathrm{~g}$ respectively) indicate that these samples were of good quality according to Ruíz-Capillas et al. (2002 b) who detected $20 \mathrm{mg} / 100 \mathrm{~g}$ VBN in the mantle of freshly caught cephalopods. Meanwhile, the present 
values were remarkably higher than those detected by Vaz-Pires et al. (2008) in other species of fresh squids and cuttlefish $(9.9$ and $7.7 \mathrm{mg} / 100 \mathrm{~g}$ muscle respectively). On the other side, the production of VBN was more intense in frozen squids $(15.93 \pm 0.01 \mathrm{mg} / 100 \mathrm{~g})$ than in fresh squids and cuttlefish. This value was lower than those in spoiled squids and cuttlefish (26.9 and 21.9 $\mathrm{mg} / 100 \mathrm{~g}$ respectively) detected by Vaz-Pires et al. (2008). All the present VBN values were below the critical limits of 25,30 and $35 \mathrm{mg} / 100 \mathrm{~g}$ specified by the European Commission guidelines (EC, 1995) for different groups of fish species.

Similar to VBN, TMA value detected for the frozen squids was significantly higher $(3.2 \pm 0.01 \mathrm{mg} / 100 \mathrm{~g})$ than that in fresh squids and fresh cuttlefish $(2.0 \pm 0.02$ and $1.7 \pm 0.02 \mathrm{mg} / 100 \mathrm{~g}$ respectively) but did not exceed the standard limit of $10 \mathrm{mg} / 100 \mathrm{~g}$ muscle (EC, 1991). Vaz-Pires et al., (2008) reported a TMA value of 0.1 and $0.3 \mathrm{mg} / 100 \mathrm{~g}$ for fresh shortfin squid and cuttlefish respectively; while they detected 8.4 and $10 \mathrm{mg} / 100 \mathrm{~g}$ in spoiled squids and cuttlefish after 10 days in ice storage. Although, the levels of VBN \& TMA in frozen squids are below the standard limits, yet the standard limits were found to vary within different species, age and sex of animals and season of harvesting (Kilinc \& Cakli, 2005).

\section{Nutritional characterization}

The highest percentage of protein was detected in the fresh samples. Results obtained for proximate composition were within the levels for 21 species of cephalopods reported by Lee (1994). He reported that the cephalopod proximate composition $(\mathrm{g} / 100 \mathrm{~g})$ is composed of $18 \mathrm{~g}$ protein and $79 \mathrm{~g}$ moisture, thus leaving only $3 \mathrm{~g}$ of body mass for other biochemical compounds needed for life. The significant decrease in protein coincided with the significant increase $(P<0.05)$ in moisture of frozen sample in agreement with Sykes et al., (2009) who found a significant decrease in protein of $S$. officinalis after 13 days of spoilage in ice. The high autoproteolytic activity of proteinases produce an increment on the water fraction that led to a loss in protein content by washing effect (Sykes et al., 2009).

Fatty acid composition significantly differed $(P<0.05)$ between frozen squids, fresh squids and fresh cuttlefish. Unsaturated fatty acids formed the highest proportion that ranged between $55.37-66.66 \%$ in fresh samples and formed $50.32 \%$ in frozen samples. Such results are approximately within the range of data published for other cephalopods by Sinanoglou \& MiniadisMeimaroglou (1998) who observed that the Mediterranean cephalopods contain large amounts of unsaturated fatty acids (52.89-56.25\% of total fatty acids). The most characteristic PUFAs are eicosapentaenoic acid (EPA; 20:5n-3, 20\%) and docosahexaenoic acid, (DHA; 22:6n-3,36\%), which agree with the results of Kilada \& Riad (2008). The slight differences in values can be explained by well known variations within aquatic species and within individuals of the same 
species, and also by diverse geographical origin and subsequently different biological and non biological factors (Rosa et al., 2000).

EPA and DHA in the fresh samples were approximately three times higher than that in frozen squids. This may emphasize the high quality of fresh cephalopods from the health perspective (Mozaffarian et al., 2005). The remarkable decrease in EPA \& DHA of frozen squids might have resulted from lipid oxidation caused by freezing (Decker \& Hultin, 1992). Lipid oxidation processes lead to discoloration, drip losses, off-flavor development and production of potentially toxic compounds (Decker \& Hultin, 1992). Furthermore, lipid oxidation in fish muscle during frozen storage showed a detrimental effect on protein structure and functionality (Saeed \& Howell, 2002).

The low percentage of EAA in frozen squids indicates that the quality of their protein might be lower than that in fresh squids and fresh cuttlefish. High percentage of $\mathrm{H}_{2} \mathrm{~S}$-producing bacteria in frozen squid can account for the change in amino acids composition, since they degrade sulfur-containing amino acids and produces volatile sulfides including $\mathrm{H}_{2} \mathrm{~S}$ (Brettar et al., 2002).

\section{Bacteriological analysis}

Total viable bacteria count (TVB) is the most common method for determination of the bacteriological quality of seafood. This measurement is seldom a good indicator of the sensory quality or expected shelf life of the seafood product (Huss et al., 1997), but it is taken as an indicator of the hygiene status of the product. The present analysis of TVB revealed that bacterial flora in frozen squids is significantly higher than that in fresh/chilled squids and cuttlefish. However, the numbers detected in all samples are relatively lower $\left(14 \times 10^{5}, 1264 \times 10^{3}, 888 \times 10^{3} \mathrm{cfu} / \mathrm{ml}\right.$ in frozen squids, fresh squids and fresh cuttlefish respectively) than the number recorded at the rejection point which is around $10^{7}$ and $10^{9} \mathrm{cfu} / \mathrm{g}$ for many fish and fish products (Huss et al., 1997).

Counts of the black colonies, which represent the $\mathrm{H}_{2} \mathrm{~S}$-producing bacteria, follow the same pattern of TVB. They were significantly higher in frozen squids than that in the fresh/chilled squids and cuttlefish. The number detected in the current study $\left(3 \times 10^{5} \mathrm{cfu} / \mathrm{ml}\right)$ was much higher than that recorded in other spoiled squids $10^{4} \mathrm{cfu} / \mathrm{cm}^{2}$ at sensory rejection time (Vaz-Pires et al., 2008). These bacteria usually constitute only a small fraction of the initial flora on newly caught fish but constitute a significant, sometimes dominant, part of the microbiota during chilled storage, and their numbers determine the shelf life of the product (Vogel et al., 2005). Shewanella putrefaciens has been considered the most common sulphide producer on fish tissues during iced storage (Brettar et al., 2002). All the Shewanella strains are able to reduce TMAO to trimethylamine (TMA) and this explains its importance in spoilage of fish stored at low temperatures where the "fishy" off-odor of spoiling fish is caused by the production of TMA (Brettar et al., 2002). Thus, the high count of $\mathrm{H}_{2} \mathrm{~S}$-producing bacteria explains the high content of TMA in frozen squid. 
The majority of the spoilage flora in fresh cuttlefish and fresh squids seems to be composed by Pseudomonas. The number of these bacteria was much higher than $\mathrm{H}_{2} \mathrm{~S}$-producing bacteria $\left(392 \times 10^{2}\right.$ versus $1612 \times 10$ in squids and $704 \times 10^{2}$ versus $1 \times 10^{3}$ in cuttlefish $\left.\mathrm{cfu} / \mathrm{ml}\right)$. These values were much higher than that recorded in spoiled squids $10^{4} \mathrm{cfu} / \mathrm{cm}^{2}$ at sensory rejection time (Vaz-Pires et al., 2008) indicating low quality of the fresh/chilled samples. Pseudomonas is one of the specific spoilage organisms (SSOs) which produce metabolites, causing off-flavors or off-odors and consequently cause consumer food rejection (Gram \& Dalgaard, 2002).

\section{CONCLUSION}

The food quality of cephalopods was found to vary significantly depending on whether it was frozen or chilled before using. Frozen squids proved to have much lower quality than chilled. This conclusion was supported by the presence of high level of VBN and TMA in frozen squids compared to the chilled squids and cuttlefish. Besides these two parameters, the decrease in total protein content in the frozen squids indicated its lower food quality than chilled squid. The present study also showed that frozen squids may be spoiled due to the presence of high number of $\mathrm{H}_{2} \mathrm{~S}$-produceing bacteria that exceeds the number recorded at the rejection point for other cephalopods (Vaz-Pires et al., 2008).

On the other hand, the EPA, DHA and EAA were significantly higher in chilled squids and cuttlefish compared to frozen squids. This may increase the suitability of the former as better food although it may be more expensive. However, the consumer should not consume any fresh/chilled cephalopods after 10 days shelf life (Vaz-Pires et al., 2008). Future research should focus on cephalopods shelf-life under different storage conditions. The storage in noncontact ice may maintain the fresh cephalopods at grade A quality for a longer time and avoid leaching of proteins and minerals (Ke et al., 1991).

\section{ACKNOWLEDGMENTS}

I am extremely thankful to Dr. Sahar El -Alfy for her kind guidance and technical assistance in bacteriological analysis. I am also grateful to Prof. Ali Gab-Alla and Dr. Raouf Kilada for their valuable criticism on drafts of this paper.

\section{REFERENCES}

Ackman, R. G. (1989). Nutritional composition of fats in seafoods. Prog. Food Nutrit. Sci., 13: 161-241. 
Albanese, D.; Cinquanta, L. ; Lanorte, M.T. and Matteo, M. Di (2005). Squid (Sepia officinalis) stored in active packaging: some chemical and microbiological changes. Ital. J. Food Sci., 17 (3): 325-332.

AOAC (1998). Official methods of analysis, 16th, ed, 4th revision. Assoc. Official Analytical Chemistry, Washington, DC. 1141 pp.

APHA (American Public Health Association). (1992). Standard Methods for Examination of Water and Wastewater. Greenberg, editor, $18^{\text {th }}$ ed. Connors and Jenkins, American Public Health Association, Washington, D. C. USA

Atrea, I.; Papavergou, A.; Amvrosiadis, I. and Savvaidis, I.N. (2009). Combined effect of vacuum-packaging and oregano essential oil on the shelflife of Mediterranean octopus (Octopus vulgaris) from the Aegean Sea stored at $4^{\circ} \mathrm{C}$. Food Microbiol., 26 (2): 166-172.

Bergey's Manual of Systematic Bacteriology (1994). Holt, j.G., N.R.Krieh, P.A. Sneath, Staley and S.T.Williams. $9^{\text {th }}$ ed. Williams and Wilkins, Co., Baltimore, Md.

Blackburn, S. (1986). Amino Acid Determination. Methods and Techniques. Marcel Dekker, New York, N. Y., 271 pp.

Brettar, I.; Christen R. and Hofle, M. G. (2002). Shewanella denitrificans sp. nov., a vigorously denitrifying bacterium isolated from the oxicanoxic interface of the Gotland Deep in the central Baltic Sea. Int. J. Syst. Evolut. Microbiol., 52:2211-2217.

Cohen, Z.; Von Shak, A. and Richmond, A. (1988). Effect of environmental conditions on fatty acid composition of the red algae Porphyridium cruentum: correlation to growth rate. J. Phycol., 24:328-332.

Decker, E. A. and Hultin, O. H. (1992). Lipid oxidation in muscle food via redox: Iron. In Lipid oxidation in food, pp. 33-54.Ed. by A. S. Angelo. Washington, DC, American Chemical Society.

EC, Council Directive 91/493 of 22 July (1991). Laying down the health conditions for the production and the placing on the market of fishery products. Official. J. Eur. Comm., L 268: 15-34.

EC, Council Directive 95/149 of 8 March (1995). Fixing the total volatile basic nitrogen (TVB-N) limit values for certain categories of fishery 
products and specifying the analysis methods to be used. Official. J. Eur. Comm., L 97: 84-87.

FAO (2004). The state of world fisheries and aquaculture. Rome, Italy: FAO Fisheries Department, Food and Agriculture of the United Nations, $153 \mathrm{pp}$.

GAO (2001). FOOD SAFETY. Report to the Committee on Agriculture, Nutrition, and Forestry, U.S. Senate.

Gram, L. and Dalgaard, P. (2002). Fish spoilage bacteria: problems and solutions. Curr.Opin. Biotechnol., 13:262-266.

Guerra, A. (1996). Explotacion mundial de cefalopodos. In Jornadas Internacionales Sobre Utilizacion de Cefalopodos: Aspectos Cientıficos y Technologicos. Instituto del Frı, Madrid.

Howgate, P. (1976). Determination of total volatile bases, TD 564. Aberdeen: Torry Research Station. Appendix 4.

Huss, H. H.; Dalsgaard, D. and Gram, L. (1997). Microbiology of fish and fish products. In Seafood from producer to consumer, integrated approach to quality, pp. 413-430. Ed. by J. B. Luten, T. Børresen, \& J. Oehlenschla“ger. Amsterdam, Elsevier.

Ke, P. J.; Fierheller, M. and Lemon, D. W. (1991). Studies on processing technology for atlantic short-fin squid (Illex illecebrosus). Food Science and Technology. Lebensm.-Wiss. Technol., 24(4): 328-333.

Kilada, R. and Riad, R. (2008). Seasonal variations in biochemical composition of Loligo forbesi (Cephalopoda:Loliginidae) in the Mediterranean sea and the gulf of Suez, Egypt. J. Shellfish Res., 27(4): 881-887.

Kilinc, B. and Cakli, S. (2005). The determination of the shelf-life of pasteurized and non-pasteurized sardine (Sardina pilechardus) marinades stored at $40^{\circ}$ C. Int. J. Food Sci. Technol., 40: 265-271.

Kreuzer, R. (1984). Cephalopods: handling, processing and products. FAO Fisheries Technical Paper, 254 pp.

Lapa-Guimaraes, J.; Felıcio, P. E. de and Contreras, E. S. G. (2005). Chemical and microbial analyses of squid muscle (Loligo plei) during storage in ice. Food Chem., 91(3): 477-483. 
Lee, P.G. (1994). Nutrition of cephalopods: fueling the system. Mar. Freshwater Behav. Physiol., 25:35-51.

Lougovois, V. P.; Kolovou, M. K.; Savvaidis, I. N. and Kontominas, M. G. (2007). Spoilage potential of ice-stored whole musky octopus (Eledone moschata). Int. J. Food Sci. Technol., 43 (7): 1286 - 1294.

Mackie, I. M. (1982). Fish protein hydrolysates. Proc. Biochem., 1: 26-31.

Mozaffarian, D.; Bryson, C. L.; Lemaitre, R. N.; Burke, G. L. and Siscovick, D. S. (2005). Fish intake and risk of incident heart failure. J. Amer.Coll. Cardio., 45(12):2015-2021.

Nilsson, K. and Ekstrand, B. (1993). The effect of storage on ice and various freezing treatments on enzyme leakage in muscle tissue of rainbow trout (Oncorhynchus mykiss). Zeitschrift fur Lenensm. Unters.Forch., 197: 3-7.

Oxoid Manual of Culture Media, Ingredients, and Other Laboratory Services. (1985). Oxoid Limited, UK.

Rosa, R. A.; Nunes, M. L. and Reis, C. S. (2000). Variacoes sazonais da composicao bioquimicado polvo-comum, Octopus vulgaris, em tres zonas da costa portuguesa. Relatorios Cientificos e Tecnicos do Instituto de Investigacao das Pescas e do Mar. 61: 26pp.

Ruiz-Capillas, C.; Moral, A.; Morales, J.and Montero, P. (2002a). The effect of frozen storage on the functional properties of the muscle of volador (Illex ciondetii). Food Chem., 78: 149-156.

Ruiz-Capillas, C.; Moral, A.; Morales, J. and Montero, P. (2002b). Characterization of non-protein nitrogen in the cephalopods volados (Illex coindetii), pota( Todaropsis eblanae) and octopus (Eledone cirrhosa). Food Chem., 76: 165-172.

Saeed, S. and Howell, N. K. (2002). Effect of lipid oxidation and frozen storage on muscle proteins of Atlantic mackerel (Scomber scombrus). J. Sci. . Food . Agric., 82: 579-586.

Sinanoglou, V.J. and Miniadis-Meimaroglou, S. (1998). Fatty acid of neutral and polar lipids of (edible) Mediterranean cephalopods. Food Res. Int., 31: 467-473. 
Sykes, A. V.; Oliveira, A. R.; Domingues, P. M.; Cardoso, C. M.; Andrade, J. P. and Nunes M. L. (2009). Assessment of European cuttlefish (Sepia officinalis, L.) nutritional value and freshness under ice storage using a developed Quality Index Method (QIM) and biochemical methods. Lebensm. - Wiss. Technol., 42 (1): 424-432.

Tyson, F.L.; Rice, D.L. and Dearry, A. (2004). Connecting the oceans and human health. Environ. Health Perspect., 112 (8): A455- A456.

Vaz-Pires, P. and Seixas, P. (2006). Development of new quality index method (QIM) schemes for cuttlefish (Sepia officinalis) and broadtail shortfin squid (Illex coindetii). Food Control, 17: 942-949.

Vaz-Pires, P.; Seixas, P.; Mota, M.; Lapa-Guimaraes, J.; Pickova, J.; Lindo, A. and Silva, T. (2008). Sensory, microbiological, physical and chemical properties of cuttlefish (Sepia officinalis) and broadtail shortfin squid (Illex coindetii) stored in ice. J. Food Sci. Tech., xx: 1-10.Vogel, B. F.;

Venkateswaran, K.; Satomi, M. and Gram, L. (2005). Identification of Shewanella baltica as the Most Important $\mathrm{H}_{2} \mathrm{~S}$-Producing Species during Iced Storage of Danish Marine Fish. App. Environ. Microbiol., 66896697.

Zlatanos, S.; Laskaridis, K.; Feist, C. and Sagredos, A. (2006). Proximate composition, fatty acid analysis and protein digestibility-corrected score of three Mediterranean cephalopods. Mol. Nut. Food Res., 50: 967-970. 